\title{
If you do not know the child's temperament you do not know the child
}

\author{
Se não se conhece o temperamento da criança, \\ não se conhece a criança
}

\author{
Carmelo CALLUENG ${ }^{1}$ \\ Thomas OAKLAND²
}

\begin{abstract}
Current scholarship generally characterizes temperament as stylistic and relatively stable traits that subsume intrinsic tendencies to act and react in somewhat predictable ways to people, events, and other stimuli. An understanding of children's temperament preferences aids our understanding of the origins of behaviors as well as normal attitudes children display at home, school, and elsewhere. The purpose of this paper is to provide an introduction to children's temperament along with a desire that this information serve to stimulate further research and applications in Brazil. The concept of temperament has evolved from a classic (Hippocrates and Galen) to a modern (Jung and Myers and Briggs) perspective. Two theoretical orientations (Thomas and Chess as well as Oakland and colleagues) provide somewhat popular methods to explain temperament constructs displayed by children and youth. This paper focuses on Oakland and colleagues' approach to temperament in children ages 8-17 in terms of the eight basic styles that are grouped into four bipolar traits: extroverted or introverted, practical or imaginative, thinking or feeling, and organized or flexible styles. Descriptions of the temperament styles and their corresponding behavioral characteristics in children are included. Findings from cross-national research on children's temperaments also are discussed.
\end{abstract}

Keywords: Child behavior; Questionnaires;Temperament.

\section{Resumo}

O conhecimento atual geralmente caracteriza temperamento como traços de estilo relativamente estáveis que classificam tendências intrínsecas para agir e reagir de maneiras mais ou menos previsíveis à pessoas, eventos e outros estímulos. Entender as preferências de temperamentos infantis nos ajuda a entender as origens dos comportamentos das crianças bem como suas atitudes cotidianas em casa, na escola ou em outros lugares. O objetivo deste artigo é fornecer uma introdução ao temperamento infantil juntamente com um desejo de que esta informação estimule estudos futuros e aplicações no Brasil. O conceito de temperamento tem evoluído da perspectiva clássica (Hipócrates e Galeno) para a moderna (Jung e Myers e Briggs). Duas referências teóricas (Thomas e Chess assim como Oakland e colaboradores) nos fornece métodos um tanto populares para explicar constructos de temperamento apresentados por crianças e jovens. Este artigo é focado na abordagem de Oakland e seus colaboradores ao temperamento de crianças entre 8 e

1 University of Nebraska, College of Education, School Psychology Department. 1615 West 24 $4^{\text {th }}$, Street, 68849 Kearney, NE, United States. Correspondência para/Correspondence to: C. CALLUENG. E-mail: <calluengcm@unk.edu>.

2 University of Florida, College of Education, Departament of Educacional Psychology. Gainiesville, FL, United States. 
17 anos que apresenta oito estilos básicos agrupados em quatro traços bipolares: extrovertido ou introvertido, prático ou imaginativo, raciocínio ou emoção, e organizado ou flexível. Descrições dos estilos de temperamento e suas características comportamentais em crianças estão incluídas. Os resultados de pesquisa transnacional abordando temperamento infantil também são discutidos.

Palavras-chave: Comportamento infantil; Questionários; Temperamento.

Parents and professional engaged with children and youth generally detect important differences in their attitudes and behaviors-often at an early age. For example, some children are practical, serious, quiet, organized, dependable, and succeed through concentration and thoroughness. In contrast, other children are warmly enthusiastic, ingenious, imaginative, readily help others, and succeed by improvising instead of preparing in advance. A closer examination of these children will reveal important value differences. The first group of children value traditions and seek to contribute to important institutions through their personal involvement in schools, families, and often religious institutions. In contrast, the second group of children values their personal development and seek continued opportunities to grow and develop, recognizing such growth occurs best when they are surrounded by harmony. These differences reflect temperament differences.

Over centuries, scholars have attempted to describe and explain the origins of these and other important temperament and personality differences-ones that often are viewed through the lens of behavioral styles, emotions, degrees of stability, and heritability (Goldsmith et al., 1987). The resulting scholarship generally characterizes temperament as stylistic and relatively stable traits that subsume intrinsic tendencies to act and react in somewhat predictable ways to people, events, and other stimuli. Temperament reflects behavioral tendencies rather than specific behaviors; temperament traits appear early in life (Goldsmith et al., 1987; Thomas \& Chess 1977) and thus are assumed to have a biological origin (Bates \& Wachs, 1994; Goldsmith et al., 1987; Kagan, 1989, 1994a, 1994b, 1998; Keogh, 2003; Oakland, Glutting, \& Horton, 1996). The development of temperament may be tempered by the environment and personal 4 choice through the process of acculturation and accommodation, an idea closely related to psychological anthropology that views culture as establishing preferred behavioral styles (Miller, 1999).

An understanding of children's temperament preferences aids our understanding of the origins of behaviors as well as normal attitudes children display at home, school, and elsewhere. Temperament can assist in identifying talent, adjusting for possible weaknesses, enhancing personal and social development, promoting an understanding of others, assessing learning styles, promoting educational development, exploring career interest, and facilitating research and evaluation studies (Oakland et al., 1996). These broad uses of temperament are closely aligned to an ultimate goal of educators and psychologists, namely to accurately describe and understand children's core qualities and to utilize this information when providing services that enable children and youth to succeed academically, socially, behaviorally, and emotionally.

The purpose of this article is to provide an introduction to children's temperament along with a desire that this information serve to stimulate further research and applications in Brazil. A brief introduction to historic and current theory that guides our understanding of temperament is followed by a more detailed discussion of correlates of temperament together with international perspectives on children's temperament.

\section{Theoretical perspective of temperament}

The concept of temperament has evolved from a somewhat simple idea related to body fluids to a more sophisticated and broad theoretical explanation that encompasses biological and environmental influences together with personal 
choice. The following discussion presents a brief introduction to historic perspective of temperament theory.

\section{Classic theory of temperament}

Hippocrates. Temperament was introduced in the Greek culture as early as the $4^{\text {th }}$ century b.C. by Hippocrates (1939, 1988, 1994). Temperament was described as behavior that clusters in four humors, namely yellow and black bile, blood, and phlegm. These were considered to be neurochemical precursors of bipolar behaviors thought to oppose each other (warm versus cool, dry versus moist). Hippocrates' temperament theory was based on the premise that all mental, emotional, and behavioral disorders are caused by natural factors such as inherited susceptibility and an imbalance of the four humors (Hergenhahn, 2001).

Galen. Galen expanded Hippocrates' four humors by translating them into four physical and emotional temperament characteristics (Galen, 1992; Hergenhahn, 2001; Hippocrates, 1939): choleric, phlegmatic, melancholic, and sanguine. Galen believed that emotional and behavioral functioning was due to the dominance of one pair of bodily states over the complementary pair (warm and moist dominating cool and dry). For example, those with a choleric type have an over supply of yellow bile that would incline persons to be both angered and calmed easily, to change moods and likes quickly, and, when extreme, to be seen as a fool. Kant added other behaviors to these four qualities (H.J. Eysenck \& Eysenck, 1985).

\section{Modern theory of temperament}

Jung. Jung's theory of temperament arose from his observations and interactions with clients seeking psychiatric services. He noted that patients with similar temperament qualities displayed similar adjustment problems. For example, he reported that patients with hysteria displayed extroverted attitudes regardless of their emotional instability.
He described these patients as being consistently aware of their surroundings and interacting actively with the therapist. On the other hand, patients with schizophrenia displayed introverted attitudes and preferred to be alone and withdrawn from others (Storr, 1991).

Jung explored the unconscious mind through the study of attitudes and values. Jung described attitude as "the psyche's ability to act or react in a certain way" (Jung, 1921/1971, p.414). The fundamental ideas in Jung's psychological typology are the two attitudes of introversion and extroversion-bipolar qualities found on every viable scale of temperament and personality. He believed every person displays both introversion and extroversion behavioral tendencies (Jung, 1921/ 1971). However, each person is thought to have a particular preference for either introversion or extroversion and most often display behaviors consistent with their preferences. Introversion and extroversion are displayed along a continuum. Thus, persons may vary from being strongly introverted to slightly introverted or strongly extroverted to slightly extroverted (Jung, 1921/1971). Introversion and extroversion bring both positive and negative qualities depending on a person's general disposition (Wehr, 1971).

Jung also identified four basic psychological functions: thinking, feeling, sensation, and intuition (Jung, 1921/1971). Each of these functions can be displayed along with extroversion and introversion. Jung viewed thinking and feeling as rational functions (Jung, 1921/1971). Persons who display a thinking preference make decisions through careful deliberation together with the use of logical and objective information. They value justice, truth, and facts. In contrast, persons who display a feeling preference base decisions on a subjective process. The value loyalty, sympathy, and harmony. These values create a sense of liking, disliking, or general mood that integrates past experiences and can lead to either accepting or rejecting a choice.

Jung believed intuition and sensation represent two different functions for acquiring and assessing information. Intuition and sensation operate in opposite directions and are considered 
irrational decision-making styles. Persons who display an intuition assimilate quickly, thus integrating past experiences and unconscious perceptions. In contrast, persons who display sensation require direct physical experiences of the world, with facts or external stimuli acquired through their physical senses. Unlike intuition, sensation is a conscious perception and acquired through concrete experience rather than by analysis.

Myers and Briggs Theory. Myers was fascinated with Jung's work, accepted his three bipolar qualities, and added a fourth: judging and perceiving. Judging and perceiving are concepts that relate to how persons prefer to structure their lives in relation to the environment. Person with a judging orientation prefer planning, systems, order, routines, standards, self-regimentation, purposeful actions, decisiveness, and closure. Persons with a perceiving orientation prefer spontaneity, understanding, tolerance, curiosity, zest for experience, and adaptability (I.B. Myers \& Myers 1980).

Myers and Briggs developed the MyersBriggs Type Indicator (MBTI) (I.B. Myers \& Myers, 1980). The MBTI combines Jung's three psychological dimensions [extroversion (E)-introversion (I), sensing (S)-intuition ( $N$ ), and thinking (T)-feeling ( $F)$ ] and added the judging (J)-perceiving ( $\mathrm{P}$ ) dimension. These four bipolar qualities yield 16 type combinations: ISTJ, ISFJ, INFJ, INTJ, ISTP, ISFP, INFP, INTP, ESTP, ESFP, ENFP, ENTP, ESTJ, ESFJ, ENFJ, and ENTJ (Quenk, 2009). The MBTI is one of the most widely used measures of temperament and personality internationally, given the breadth of its applications for adults (Joyce, 2010).

\section{Temperament construct for children and youth}

Early theory and research on temperament were conceptualized on adult behavior patterns. However, theorists agree that temperament dispositions are early appearing and that temperament differences are present as early as infancy, thus suggesting temperament is innate or biologically rooted (Jung, 1928/1945; Rothbart, 6 1989; Teglasi, 1998a; Teglasi, 1998b). Differences in infants' activity levels, sociability, and emotionality reflect their temperaments (Buss, 2011; Jung (1928/ 1945; Thomas \& Chess, 1989) described infants' adaptation to the environment, especially how quickly they interact with objects and other people, as an early sign of extroversion. Indicators of introversion in children include shyness, reflective thinking, and fearfulness of unknown objects and persons.

\section{Thomas and chess temperament theory}

Thomas and Chess $(1977,1989)$ developed a framework for understanding children's temperaments based on behavioral characteristics that helped explain the similarities between behavioral styles and temperament. Behavioral style describes how a person behaves rather than how well, what (abilities and content), or why (motivation) a person behaves. The term behavioral style refers to behavioral characteristics that are present at birth and throughout life. In contrast, temperament refers to preferred behavioral tendencies. They too appear in early infancy and may last throughout life. Temperament measures for children and adults generally assess preferences, not behaviors.

Thomas and Chess considered development as a complex interplay between the child and the environment. They believed temperament is best understood when it is described in the context of a child's environment. They used the concept of goodness of fit to explain the temperamentenvironment interactive process. Goodness of fit occurs when there is a good match between the preferred characteristics of the child and the preferred characteristics of the environment. Poorness of fit occurs when there is a mismatch between the child's preferred characteristics and those of the environment.

Thomas and Chess identified three somewhat common temperament styles in infants: easy, difficult, and slow-to-warm-up. An easy temperament was displayed by approximately $40 \%$ 
of the infants. They were described as being able to establish regular routines, were cheerful, adapt easily to new situations, contented, and easy going. A difficult temperament was displayed by approximately $10 \%$ of the infants. About $70 \%$ of these children later encountered long-term adjustment problems at some point in the future. They were described as experiencing irregular routines, problematic sleep cycles, were slow to adapt to new circumstances, and tended to react negatively to persons and events. A slow-to-warm temperament was displayed by approximately $50 \%$ of the infants. They were described as watchful of strangers, lethargic, tending to display a negative mood, and to adjust rather slowly to new situations. Approximately $35 \%$ of the infants displayed a combination of temperament styles.

\section{Oakland's approach to children's temperament}

Oakland and colleagues (Oakland et al., 1996) developed the Student Styles Questionnaire (SSQ) in an effort to better understand the temperament qualities of children and youth, ages 8-18. The SSQ is based on the previously discussed Myers/Briggs model of temperament and thus describes children's temperament through eight basic styles that are grouped into four bipolar traits: extroverted or introverted, practical or imaginative, thinking or feeling, and organized or flexible styles. In turn, the basic styles can form 16 meaningful combinations with four styles (one of the 16 is extroverted-practical-thinking-organized styles) in each combination (Oakland et al., 1996). Each of the temperament qualities is discussed below.

Extroverted-introverted traits. Knowledge of extroverted-introverted traits helps us understand the primary source from which children derive energy. Those who prefer an extroverted style generally derive energy primarily from the external environment and thus are more oriented to people. In contrast, those who prefer an introverted style generally derive energy primarily from themselves and thus are more oriented to their personal ideas and reflection.
Children who prefer an extroverted style. Children who prefer extroverted style generally enjoy meeting and interacting with people. They exhibit higher energy levels, socialize readily and often, and enjoy discussing different topics. They are drawn to participate in group activities and experience discomfort when required to spend too much time alone. Socially, they move easily from situation to situation, learning people's names, and engaging in conversation.

In school, children with an extroverted style preference develop their thoughts and ideas by discussing them and thus thrive in a learning environment in which they have opportunities to participate and talk. Positive behaviors are reinforced through encouragement and praises. They may not be comfortable when working on long assignments or seatwork. They also tend to act without thinking and planning. Their desire for interaction may disrupt the classroom environment and, at an extreme, may be annoying to students who display strong preference for an introverted style.

Children who prefer an introverted style. Children who prefer introverted style are likely to enjoy being alone or with a small group of likeminded peers. They may feel exhausted and bored following intense and long periods of social interaction. They generally respond to their surrounding slowly and display a wait-and-see attitude before joining an activity. They generally are cautious and prefer to listen than to talk when in a group. Although they may have fewer friends, their friendships tend to be more intimate. They tend to be more private and thus more selective of people with whom they want to be close. Their reserved and quiet manner may be misinterpreted as lacking adequate social skills.

In school, children with an introverted style preference can work for long hours on a project without interruption. They prefer to work alone or with a small group of students who match their behavioral qualities. They like doing tasks that draw on their methodical, reflective, and reasoning skills. They prefer to be called on by the teacher to recite in class rather than volunteer to recite. Unfortunately, 
at times, teachers and other adults may label them as unfriendly, uncooperative, and withdrawn because of their preference to be alone and quiet.

Practical-imaginative trait. Knowledge of practical-imaginative traits helps us understand how children prefer to learn and process information. Those who prefer a practical style generally have realistic and pragmatic views of the world. They tend to attend more to details and facts when acquiring information than to theories and generalizations. In contrast, those who prefer imaginative style generally do best when their creative qualities and interests are used. They assimilate information readily. Thus, they tend to attend to theories and generalizations more than to details and facts.

Children who prefer a practical style. Children who prefer a practical style generally are keen observers and use their physical senses to understand their environments. Although they generally attend to details well, they may be less able to assimilate and synthesize details needed to form a broad understanding. They generally enjoy traditions, recreation, leisure time, and the company of their family. To them, the present is more important than the distant future.

In school, children with a practical style preference generally enjoy learning through the use of well sequenced (step-by-step) methods. They tend to be organized, have good rote memory, and persist in working toward their goals. They prefer to engage in subjects that have practical value in their lives and thus tend to become disinterested in learning complex material and abstract concepts.

Children who prefer an imaginative style. Children who prefer an imaginative style generally enjoy acquiring new skills. They love ideas and concepts that stimulate new and keen insights rather than facts and sensory-based knowledge. They generally are more engaged in tasks that require comprehension, analysis, and formulating conclusions. They are proud of their ability to assimilate facts into logical summaries. They prefer to learn the theory first and proceed to know its usefulness and application. They generally have 8 close relationships with their family.
In school, children with an imaginative style preference often acquire an understanding of somewhat complex issues and learn novel tasks quickly. They enjoy proposing and testing hypothesis and generating insights about their experiences. They generally prefer to work on projects and assignments that require imagination and analysis. They are fascinated to learn new theories, even trivial ones that lack empirical evidence. At times, they come up with very complex and sophisticated plans that can be difficult to implement. They may overlook important details.

Thinking-feeling traits. Knowledge of thinking-feeling traits helps us understand how children make decisions. Those who prefer a thinking style rely principally on their thoughts, leading to decisions that are likely to be fair, objective, and logical. In contrast, those who prefer a feeling style rely principally on their feelings and emotions, leading to decisions that are sympathetic and supportive.

Children who prefer a thinking style. Children who prefer a thinking style generally are engaged in activities that require analysis of facts and ideas. They are inclined to be skeptical of what they hear and read and typically ask questions before being convinced about other's ideas. Their opinions and beliefs tend to be firm and somewhat consistent. They are likely to enjoy the company of peers who share common interests. When with friends, they prefer tasks that stimulate their logical and analytical skills rather than engage in superficial social conversation. They enjoy playing with ideas that may not be supported by evidences. They tend to criticize themselves and others-at times offending others with criticisms that seem to be harsh. Although they tend to be close to their family members, they are less likely to express their love and affection either verbally or non-verbally. They cooperate and follow family rules that seem fair and reasonable.

In school, children with a thinking style preference often sustain attention during lectures and presentation that are organized logically. They are more likely to enjoy subjects that require the 
use of logical and analytical skills (math and science) and less likely to enjoy those that rely on an expression of feelings (art, romantic literature).

Children who prefer a feeling style Children who prefer a feeling style rely on their emotions and interpersonal relationship when making decisions. They tend to be friendly, charming, sympathetic, generous, caring, and empathetic. They generally support or participate in projects that promote human welfare, peace, and harmony. Thus, they tend to avoid conflict or disagreement with others that may strain relationships or hurt other's feelings. Their desire to achieve harmony prevents them, at times, from honestly expressing their thoughts and feelings. They generally display affection and love toward their family. However, family conflict or disagreement may cause considerable distress.

In school, children with a feeling style preference tend to enjoy subjects or lessons that focus on people (history, psychology, literature). Praise and other forms of affirmation are effective strategies to motivate them to perform well. When working in groups, they prefer to work with friends or to assist others who may need their assistance. They are more likely to be cooperative than competitive in school-related activities.

Organized-flexible traits. Knowledge of organized- flexible traits helps us understand when a person prefers to make decisions. Those who prefer an organized style generally make decisions rather quickly and in a planned manner. In contrast, those who prefer a flexible style generally postpone decisions and rush to complete them just before they are due.

Children who prefer an organized style. Children who prefer organized style generally structure and plan their activities and thus complete them in an organized way. They prefer an orderly and routine lifestyle and may rely on lists to help structure their time. They generally display and expect to receive loyalty and support between friends. They may devote considerable time preparing for activities and may become upset when changes are made without consulting them. They prefer a well-planned home life and expect parents and other family members to fulfill their promises. They generally are obedient to rules and complete chores in an orderly way.

In school, children with an organized style preference generally display an admirable selfregulated work ethic (persistence, dependable, and self-disciplined), generally have good study habits, complete assignments on time, and are in control of their school activities. They generally respect authority. Others see them as responsible, obedient, and dependable. They also expect teachers to display these qualities by providing explicit instructions and guidelines related to grading, examinations, assignments, and classroom behavior. They generally put forth their best effort to attain goals and are motivated to maintain good work and behavior through consistent praises and rewards.

Children to prefer a flexible style. Children who prefer a flexible style generally are adaptable and thus tend to adjust easily to changes in their lives and enjoy surprises. The role of rules in their lives can be somewhat complex. They have a high need for autonomy and thus may resist rules at home and school. They are likely to reject rules that make little sense to them or are too confining, especially those that are imposed on them. They are likely to abide by rules when they are selfimposed and that are sensible to them. They generally seek fun activities, have difficulty coping with stress and problems, and thus strive to avoid them. Their social relationships tend to be flexible in style and often shorter in duration. They also discard relationships that become too confining. They generally accept diversity and tolerate different opinions. They prefer their family to be a source of fun and to minimize stress on them. Their personal room or space may not be organized or neat.

In school, children with a flexible style preference generally do best when they can turn work into play. Thus, they are likely to enjoy lessons and activities if presented in a game-like manner. They like to participate and perform in school 
activities especially when there are incentives for winning. They do best in classroom environments that provide options, have flexible deadlines for assignment and projects, allow them to move around the room, and have few rules. They enjoy entertaining others and may become the class clown, making people laugh and have fun.

\section{Cross-national differences in children's temperament}

International interest in children's temperament, including possible age and gender differences, led to considerable scholarship, including cross-national studies on children's temperament traits, including the validation of the SSQ's adaptation (Benson, Oakland, \& Shermis, 2009). Temperament preferences were examined in light of the four bipolar qualities measured by the SSQ in children from 17 countries: Australia (Oakland, Faulkner, \& Bassett, 2005), China (Oakland \& Lu, 2006), Costa Rica (Oakland \& Mata, 2007), Gaza (Oakland, Alghorani, \& Lee, 2006), Greece (Oakland \& Hatzichristou, 2010), Hungary (Katona \& Oakland, 2000), India (Oakland, Singh,
Callueng, Puri, \& Goen, 2011), Japan (Callueng, Carvalho Filho, Isobe, \& Oakland, 2012), Nigeria (Oakland, Mogaji, \& Dempsey, 2006), Pakistan (Oakland, Rizwan, Aftab, \& Callueng, 2011), Romania (Oakland, Illiescu, Dinca, \& Dempsey, 2009), South Africa (Oakland, Pretorisus, \& Lee, 2008), Samoa (Callueng, Lee Hang, Gonzales, LingSo'o, \& Oakland, 2011), South Korea (Oakland \& Lee, 2010), United States (Bassett \& Oakland, 2009), Venezuela (Leon, Oakland, Wei, \& Berrios 2009), and Zimbabwe (Oakland, Mpofu, \& Sulkowski, 2007) were examined in light of the four bipolar traits measured by the SSQ. A synthesis of data from these countries suggests that children display several prevailing temperament qualities. A summary of the temperament preferences of children in 18 countries is found in Table 1. Age and gender differences on children's temperaments by country are summarized in Table 2.

\section{Extroversion-introversion styles examined cross-culturally}

Children from 13 countries generally display a preference for an extroversion style. In contrast, children from Nigeria generally display a preference

Table 1

Temperament preferences of children from 17 countries (in percent)

\begin{tabular}{|c|c|c|c|c|c|c|c|c|}
\hline Country & $E$ & I & $\mathrm{P}$ & $\mathrm{M}$ & $\mathrm{T}$ & $\mathrm{F}$ & $\mathrm{O}$ & $\mathrm{L}$ \\
\hline Australia & 54 & 46 & 36 & 64 & 65 & 35 & 55 & 45 \\
\hline China & 59 & 41 & 61 & 39 & 58 & 42 & 86 & 14 \\
\hline Costa Rica & 68 & 32 & 32 & 68 & 53 & 47 & 89 & 11 \\
\hline Gaza & 46 & 54 & 64 & 36 & 40 & 60 & 88 & 12 \\
\hline Greece & 76 & 24 & 51 & 49 & 53 & 47 & 74 & 26 \\
\hline Hungary & 66 & 34 & 41 & 59 & 62 & 38 & 78 & 22 \\
\hline India & 56 & 44 & 56 & 44 & 44 & 56 & 73 & 27 \\
\hline Japan & 66 & 34 & 70 & 30 & 50 & 50 & 67 & 33 \\
\hline Nigeria & 44 & 56 & 80 & 20 & 44 & 56 & 93 & 7 \\
\hline Pakistan & 59 & 41 & 56 & 44 & 48 & 52 & 83 & 17 \\
\hline Romania & 67 & 33 & 61 & 39 & 58 & 42 & 70 & 30 \\
\hline Samoa & 70 & 30 & 89 & 11 & 63 & 37 & 98 & 2 \\
\hline South Korea & 77 & 23 & 31 & 69 & 39 & 61 & 46 & 54 \\
\hline United States & 55 & 45 & 42 & 58 & 52 & 48 & 70 & 30 \\
\hline Venezuela & 74 & 26 & 55 & 45 & 60 & 40 & 82 & 18 \\
\hline Zimbabwe & 52 & 48 & 77 & 23 & 41 & 59 & 94 & 6 \\
\hline
\end{tabular}


Summary of gender and age differences in temperament preferences of children from 17 countries

\begin{tabular}{|c|c|c|c|c|c|c|c|c|}
\hline \multirow[b]{2}{*}{ Country } & \multicolumn{4}{|c|}{ Gender difference } & \multicolumn{4}{|c|}{ Age difference } \\
\hline & $\mathrm{El}$ & PM & $\mathrm{TF}$ & $\mathrm{OL}$ & $\mathrm{El}$ & PM & TF & $\mathrm{OL}$ \\
\hline Australia & & & $\checkmark$ & & & & & \\
\hline China & & $\checkmark$ & $\checkmark$ & & $\checkmark$ & & & $\checkmark$ \\
\hline Costa Rica & & & $\checkmark$ & $\checkmark$ & $\checkmark$ & & & $\checkmark$ \\
\hline Gaza & & & $\checkmark$ & $\checkmark$ & $\checkmark$ & & & \\
\hline Greece & & & $\checkmark$ & $\checkmark$ & & & & $\checkmark$ \\
\hline Hungary & & & $\checkmark$ & & $\checkmark$ & & & \\
\hline \multicolumn{9}{|l|}{ India } \\
\hline Japan & & & $\checkmark$ & $\checkmark$ & & & & $\checkmark$ \\
\hline Nigeria & & & $\checkmark$ & $\checkmark$ & & & & $\checkmark$ \\
\hline Pakistan & & $\checkmark$ & $\checkmark$ & $\checkmark$ & & $\checkmark$ & & $\checkmark$ \\
\hline Romania & & & & & & & $\checkmark$ & $\checkmark$ \\
\hline Samoa & & $\checkmark$ & & & & & & \\
\hline South Africa & & & $\checkmark$ & & & & & $\checkmark$ \\
\hline South Korea & & & & & $\checkmark$ & $\checkmark$ & & $\checkmark$ \\
\hline United States & & $\checkmark$ & $\checkmark$ & $\checkmark$ & & $\checkmark$ & & \\
\hline Venezuela & & & $\checkmark$ & & & & & $\checkmark$ \\
\hline Zimbabwe & & & & & & & & $\checkmark$ \\
\hline
\end{tabular}

Note: E: Extroverted; I-Introverted; P: Practical; M: Imaginative; T: Thinking; F: Feeling; O: Organized; L: Flexible.

for an introversion style. Children from Gaza, South Africa, and Zimbabwe show a somewhat balanced preference for extroversion and introversion styles. Age differences are evident in six countries. Compared to younger children, older children (15 year-olds) from China, Costa Rica, Gaza, Hungary, and South Korea are more likely to prefer introverted to extroverted styles. Gender differences on children's preferences for extroversion and introversion styles are not apparent.

\section{Practical-imaginative styles examined cross-culturally}

Children from 11 countries show a general preference for a practical style. In contrast, children from four countries generally show a preference for an imaginative style. Children from Greece display a somewhat a balanced preference for practical and imaginative styles. Gender differences are evident among children from China, Pakistan, Samoa, and United States with more males preferring an imaginative style and more females preferring a practical style. Few age differences are evident. Older children from South Korea show a greater preference for a practical style while older children from Pakistan and the United States show a greater preference for an imaginative style.

\section{Thinking-feeling styles examined cross-culturally}

Children from most countries display somewhat balanced preferences for thinking and feeling styles. Gender differences in the thinking and feeling styles are apparent in children from Australia, China, Costa Rica, Gaza, Greece, Hungary, Japan, Nigeria, Pakistan, South Africa, United States, and Venezuela. Males generally prefer a thinking style and females generally prefer a feeling style. Both male and female children from India, South Africa, South Korea, and Zimbabwe show a general preference for a feeling style. Samoan male and female children show a preference for a thinking style. Age differences on children's preferences for thinking and feeling styles are rare and not consistent. 


\section{Organized-flexible styles examined cross-culturally}

Children from 17 countries generally show a preference for an organized style. Children from seven countries show gender difference, with females preferring an organized style and males preferring a flexible style. Age related differences are evident in children from 12 countries. A preference for flexible style generally increases with age.

\section{References}

Bassett, K., \& Oakland, T. (2009). Temperament preferences for children ages 8 through 17 in a nationally represented sample. In J. Kaufman (Ed.). Intelligent testing: Integrating psychological theory and clinical practice (pp. 30-52). Boston: Cambridge University Press.

Bates, J. E., \& Wachs, T. D. (Eds.), (1994). Temperament: Individual differences of the interface of biology and behavior. Washington, DC: American Psychological Association.

Benson, N., Oakland, T., \& Shermis, N. (2009). Crossnational invariance of children's temperament. Journal of Psychoeducational Assessment, 27(1), 3-16.

Buss, A. H. (2011). Pathways to individuality: Evolution and development of personality traits. Washington, DC: APA.

Callueng, C., Carvalho Filho, M. K., Isobe, M., \& Oakland, T. (2012). Temperament styles of children from Japan and the United States: A cross-national study. Educational Measurement and Evaluation Review, 3, 3-23.

Callueng, C. M., Lee Hang, D. M., Gonzales, R. C., LingSo'o, A. C., \& Oakland, T.D. (2011). Temperament styles of children from Samoa and the United States. Educational Measurement and Educational Review, 2, 18-34

Eysenck, H. J., \& Eysenck, M. W. (1985). Personality and individual differences: A natural science approach. New York: Plenum.

Galen (1992). The art of cure-extracts from Galen: Maimonides' medical writings. Haifa, Israel: Maimonides Research Institute. (Original work published date unknown).

Goldsmith, H. H., Buss, A. H., Plomin, R., Rothbart, M. K., Thomas, A., Chess, S., et al. (1987). Roundtable: What is temperament? Four approaches. Child
Hergenhahn, B. R. (2001). An introduction to the history of psychology ( $4^{\text {th }}$ ed.). Belmont, CA.: Brooks/Cole.

Hippocrates. (1939). Hippocrates, 1. Cambridge, MA: Harvard University Press. (Original work published date unknown).

Hippocrates (1988). Hippocrates, 5. Cambridge, MA: Harvard University Press. (Original work published date unknown).

Hippocrates (1994). Hippocrates, 7. Cambridge, MA: Harvard University Press. (Original work published date unknown).

Jung, C. G. (1945). Contributions to analytical psychology. New York: Kegan Paul, Trench, Trubner. (Original work published 1928).

Jung, C. G. (1971). Psychological types. Princeton, NJ: Princeton University Press. (Original work published 1921).

Joyce, D. (2010). Essentials of temperament assessment. New York: Wiley.

Kagan, J. (1989). Temperamental contributions to social behavior. American Psychologist, 44(4), 668-674.

Kagan, J. (1994a). Galen's prophecy: Temperament in human nature. New York: Basic Books.

Kagan, J. (1994b). Inhibited and uninhibited temperaments. In W.B. Carey \& S.C. McDevitt (Eds.), Prevention and early intervention: Individual differences as risk factors for the mental health of children (pp.35-41). New York: Brunner Mazel.

Kagan, J. (1998). Biology and the child. In W. Damon \& N. Eisenberg (Ed.), Handbook of child psychology: Vol. 3. (5 $5^{\text {th }}$ ed., pp.105-176). New York: Wiley.

Katona, N., \& Oakland, T. (2000). The development of temperament in Hungarianchildren. Hungarian Journal of Psychology, 1, 17-29.

Keogh, B. (2003). Temperament in the classroom. New York: Brooks Publishing.

Leon, C., Oakland, T., Wei, Y., \& Berrios, M. (2009). Venezuelan children's temperament styles and comparison with their United States peers. Revista Interamericana de PsicologíalInteramerican Journal of Psychology, 43, 407-415.

Miller, J. G. (1999). Cultural psychology: Implications for basic psychological theory. Psychological Science, 10(2), 85-91.

Myers, I. B., \& Myers, P. B. (1980). Gifts differing: Understanding personality type. Palo Alto, CA: Consulting Psychological Press.

Oakland, T. Faulkner, M., \& Bassett, K. (2005). Temperament styles of children from Australia and the United States. Australian Educational and Developmental Psychologist, 19(1), 35- 51.

Oakland, T., Glutting, J., \& Horton, C. (1996). Student styles questionnaire. San Antonio, TX: The Psychological Corporation. 
Oakland, T., Alghorani, M. A., \& Lee. D. H. (2006). Temperament-based learning styles of Palestinian and US children. School Psychology International, 28(1), 110-128.

Oakland, T., Mogaji, A., \& Dempsey, J. (2006). Temperament styles of Nigerian and U.S. children. Journal of Psychology in Africa, 16(1), 27-34.

Oakland, T., \& Lu, L. (2006). Temperament styles of children from the people's Republic of China and the United States. School Psychology International, 27(2), 192-208.

Oakland, T., \& Mata, A. (2007). Temperament styles of children from Costa Rica and the United States. Journal of Psychological Type, 67(10), 91-102.

Oakland, T., Mpofu, E., \& Sulkowski, M. (2007). Temperament styles of Zimbabwe and U.S. children. Canadian Journal of School Psychology, (1/2), 139-153.

Oakland, T. Illiescu, D., Dinca, M., \& Dempsey, A. (2009). Temperament styles of Romanian children. Psihologia Sociala, 22(2), 70-84.

Oakland, T., \& Lee, D. H. (2010) Temperament styles of children from South Korea and the United States. School Psychology International, 31(1), 77-94.

Oakland, T., \& Hatzichristou, S, (2010) Temperament styles of children from Greece and the United States. School Psychology International, 31(4), 422-437.

Oakland, T., Pretorius, J., \& Lee, D. H. (2008). Temperament styles of children from South Afric and the United States. School Psychology International, 29(5), 627-639.

Oakland, T., Rizwan, M., Aftab, S., \& Callueng, C. (2011). Temperament styles of children from Pakistan and the United States. School Psychology International, 33(2), 207-222.

Oakland, T., Singh, K, Callueng, C., Puri, G.S., \& Goen, A. (2011). Temperament styles of Indian and U.S. children. School Psychology International, 32(6), 655-670.

Quenk, N. L. (2009). Essentials of Myers-Briggs type indicator assessment ( $2^{\text {nd }}$ ed.). New York: John Wiley \& Sons.

Rothbart, M. K. (1989). Temperament and development. In G.A. Kohnstamm, J. E. Bates \& M. K. Rothbart (Eds.), Temperament in childhood (pp.187-247). Chichester, UK: Wiley.

Storr, A. (1991). Jung. New York: Routledge.

Teglasi, H. (1998a). Introduction to the mini-series: Implications of temperament for the practice of school psychology. School Psychology Review, 27, 475-478.

Teglasi, H. (1998b). Temperament constructs and measures. School Psychology Review, 27, 564-585.

Thomas, A., \& Chess, S. (1977). Temperament and development. New York: Brunner/Mazel.

Thomas, A., \& Chess, S. (1989). Temperament and personality. In G.A. Kohnstamm, J. E. Bates \& M. K. Rothbart (Eds.), Temperament in childhood (pp.249-261). New York: Wiley.

Wehr, G. (1971). Portrait of Jung: An illustrated biography. New York: Herder and Herder.

Received on: 25/2/2013

Final version on: 5/8/2013

Approved on: 17/9/2013 
